\title{
TOTOBUANG
}

\begin{tabular}{lll}
\hline Volume 9 & Nomor 2, Desember 2021 & Halaman 331-342
\end{tabular}

\section{PEMERTAHANAN BAHASA DAERAH DI KOTA AMBON: STUDI KASUS BAHASA DAERAH DI NEGERI LAHA SEBAGAI SATU-SATUNYA BAHASA DAERAH DI KOTA AMBON \\ (Local Language Maintenance in the city of Ambon: A Local Language Case Studying in the Laha Village as a Local Language only in the City of Ambon)}

\author{
Harlin \\ Kantor Bahasa Provinsi Maluku \\ Kompleks LPMP, Jalan Tihu, Wailela, Rumah Tiga, Kota Ambon \\ Po-sel: harlinturiah@gmail.com
}

Diterima: 11 Oktober 2021; Direvisi: 15 November 2021; Disetujui: 15 Desember 2021

doi: https://doi.org/10.26499/ttbng.v9i1.337

\begin{abstract}
The purpose of this research is to describe local language maintenance in Laha village as the only local language in the City of Ambon. The kind of this research uses quantitative desceiptive. The method of this research is qualitative method where questionnaires were specifically given to 50 respondents that were chosen randomly (random sampling). Beside that, the writer also interviewed some informants and did observation in Laha village and some decent villages in Ambon. The result of this research showed that the condition of local language in Laha village is in danger of extinction. It is shown from local language mastery in society, speakers' age, first language use, mother tongue, mastery period of local language, and local language acquisition in Laha village. Most speakers of Laha local language can only communicate with little local language of Laha (passive speakers). In terms of age, most of the fluent speakers of local language of Laha are above 50. Those who are under 50 can communicate limitedly, passively understand the language, and even some of them can not communicate using the language at all.
\end{abstract}

Keywords: local language, Laha village, in extinction danger

\begin{abstract}
Abstrak
Tujuan penelitian ini adalah untuk mendeskripsikan pemertahanan bahasa daerah yang ada di Negeri Laha (setingkat desa) sebagai satu-satunya bahasa daerah yang ada di Kota Ambon. Jenis penelitian ini menggunakan deskriptif kuantitatif. Metode dalam penelitian ini adalah metode kuantitatif yang secara spesifik responden diberikan kuesioner atau daftar tanyaan dengan jumlah sampel sebanyak 50 orang yang diambil secara acak (random sampling). Daftar tanyaan penelitian secara umum meliputi situasi dan kondisi bahasa daerah yang ada di Negeri Laha termasuk pemakai dan pemakaiannya. Hasil penelitian ini menunjukkan bahwa sekarang ini, kondisi bahasa daerah yang ada di Negeri Laha Kota Ambon terancam punah. Hal itu terlihat dari penguasaan bahasa daerah dalam masyarakat, usia penutur, bahasa yang digunakan ketika masa kecil (anakanak), bahasa pertama yang dipelajari, masa penguasaan bahasa daerah, dan pemerolehan bahasa daerah di Negeri Laha. Kemampuan penguasaan berkomunikasi dalam bahasa daerah di Negeri Laha lebih banyak hanya bisa berkomunikasi secara sedikit-sedikit daripada bisa berkomunikasi secara aktif. Dari segi usia, kebanyakan yang dapat dan lancar berbahasa daerah Laha rata-rata usia di atas 50 tahun. Untuk usia di bawah usia 50 tahun, kebanyakan dapat berkomunikasi secara sedikit-sedikit, bisa memahami (pasif), dan sebagian pula tidak bisa berkomunikasi sama sekali.
\end{abstract}

Kata-kata kunci: bahasa daerah, Negeri Laha, terancam punah

\section{PENDAHULUAN}

Secara sosial kemasyarakatan, seseorang tidak lagi dipandang sebagai individu yang terpisah dari orang lain tetapi bagian dari kelompok sosialnya. Begitu pula bahasa dan pemakaian bahasa tidak diamati secara sesuatu yang individu pula, tetapi selalu dihubungkan dengan kegiatannya dalam masyarakat. Apabila sesuatu bahasa lebih banyak dipakai, maka bahasa itu akan 
berkembang. Sebaliknya, bahasa yang tidak banyak dipakai, kosakatanya akan terdesak oleh pemakaian bahasa yang lebih dominan. Jika hal tersebut berlangsung terus, maka bisa diramalkan bahwa bahasa tersebut akan mengalami kepunahan. Seperti yang dikemukakan oleh Darwis (2011), bahwa suatu bahasa secara terus-menerus mengalami pengurangan jumlah penutur sehingga pada akhirnya kehilangan atau kehabisan jumlah penutur asli sama sekali, maka bahasa itu sudah jelas akan bernasib punah. Pemertahanan bahasa dilakukan agar tetap menggunakan bahasanya sebagai suatu identitas seseorang atau kelompok baik dalam masyarakat sendiri maupun di luar masyarakat. Hal itu dilakukan agar bahasa daerahnya atau bahasa negaranya tetap bertahan dan lestari. Pemertahanan bahasa juga diperlukan oleh suatu bangsa atau daerah dalam menunjukkan eksistensi dirinya. Tidak bisa dimungkiri bahwa konsep pemertahanan bahasa sangat terkait dengan perencanaan bahasa (Kaplan dalam Istianingrum, 2015). Keberadaan suatu bahasa tidak terlepas dari sikap para penutur bahasa yang bersangkutan, untuk digunakannya dalam kehidupan sehari-hari (Maemunah, 2017). Jumlah penutur yang besar tidak menjadi selalu penting dalam pemertahanan bahasa, kelompok kecil pun dapat mempertahankan bahasanya jika mereka memiliki sikap positif terhadap bahasanya. Pemertahanan bahasa juga mencakup perubahan bahasa (language change), peralihan bahasa (language shift), dan kematian bahasa (language death). Setakat dengan itu, Fauzi (Suandi, 2014) dan Fauzi (Nugroho, 2017) mengemukakan bahwa jika suatu komunitas bahasa tidak mampu mempertahankan bahasanya, secara bertahap memungut kosakata bahasa yang lain, maka akan mengarah kepada pergeseran bahasa.

Negeri (setingkat desa) Laha adalah salah satu negeri yang berada di Kecamatan Teluk Ambon, Kota Ambon, Provinsi Maluku. Wilayah Negeri Laha berbatasan langsung dengan wilayah Kabupaten Maluku Tengah yang berada di Pulau Ambon. Negeri Laha memiliki bahasa daerah sendiri yang dituturkan di Negeri Laha. Bahasa daerah Laha merupakan satu-satunya bahasa daerah yang masih digunakan di wilayah Kota Ambon. Berdasarkan peta bahasa yang diterbitkan dan dipublikasi oleh Badan Pengembangan dan Pembinaan Bahasa, Kementerian Pendidikan dan Kebudayaan, bahasa daerah yang ada di Negeri Laha adalah bahasa Asilulu dialek Laha. Selain dialek Laha, bahasa Asilulu memiliki 14 (empat belas) dialek lain yang ada di Provinsi Maluku. Sebaran 14 dialek tersebut meliputi 1) dialek Hatuhaha Pulau Haruku dituturkan di Desa Pelauw, Kailolo, Kabauw, Rohomoni, Hulaliu, 2) dialek Sirisori Pulau Saparua dituturkan di Desa Sirisori Islam, 3) dialek Tanah Titawaai Pulau Nusa Laut, dituturkan di Desa Titawaai, 4) dialek Asilulu Pulau Ambon dituturkan di Desa Asilulu, Larike, Negeri Lima, 5) dialek Hitu Pulau Ambon dituturkan di Desa Hitulama, Hitumessing, Mamala, Morella, Wakal, Hila, 6) dialek Tulehu Pulau Ambon dituturkan di Desa Tulehu, Tial, Tengah Tengah, Liang, 7) dialek Amahai Pulau Seram dituturkan di Desa Amahai, Ruta, 8) dialek Sepa di Pulau Seram dituturkan di Desa Sepa, 9) dialek Tamilow Pulau Seram dituturkan di Desa Tamilow, 10) dialek Tehoru Pulau Seram dituturkan di Desa Tehoru, 11) dialek Huaulu Pulau Seram dituturkan di Desa Huaulu, 12) dialek Koa Pulau Seram dituturkan di Desa Airbesar Manusela, 13) dialek Kaitetu Pulau Ambon dituturkan di Desa Kaitetu, Seith, 14) dialek Elpaputih Pulau Seram dituturkan di Desa Elpaputih (http://petabahasa.kemdikbud.go.id).

Sekarang ini, penutur bahasa daerah di Negeri Laha diduga hanya dituturkan pada sebagian kecil penduduk dari total penduduk 7.167 jiwa (BPS Kota Ambon, 2016). Selain itu, dari segi pemakaian, bahasa daerah di Negeri Laha juga diduga terus mengalami penurunan penggunaan dalam aktivitas sehari-hari di masyarakat baik dalam situasi 
resmi maupun tidak resmi. Berdasarkan gambaran di atas, peneliti melakukan penelitian dengan judul "Pemertahanan Bahasa Daerah di Kota Ambon: Studi Kasus Bahasa Daerah di Negeri Laha Kota Ambon". Tujuan penelitian ini adalah untuk mendeskripsikan pemertahanan bahasa daerah di Negeri Laha Kota Ambon. Manfaat penelitian ini agar bahasa daerah yang ada di Negeri Laha terpelihara, bertahan, dan lestari, serta sebagai bahan acuan pemerintah untuk menentukan langkah tepat dalam mengatasi permasalahan bahasa daerah di Kota Ambon yang merupakan satu-satunya bahasa daerah yang masih ada.

Secara umum, berdasarkan penelusuran yang telah dilakukan oleh peneliti, penelitian tentang pemertahanan bahasa di Indonesia sudah dilakukan oleh beberapa orang di antaranya Pemertahanan Bahasa Bajo di Desa Tanjung Luar Kecamatan Keruak Lombok Timur oleh H. Ahmad Djalaludin, Pemertahanan Bahasa Sindang Pada Masyarakat Kota Lubuklinggau oleh Nur Nisai Muslihah, dkk, dan Pemertahanan Bahasa Melayu Palembang Melalui Media Elektronik oleh Emawati. Secara umum, perbedaan penelitian ini dengan penelitian sebelumnya di antaranya 1) pemertahanan bahas a difokuskan pada ranah remaja dan dewasa seperti penelitian Pemertahanan Bahasa Sindang Pada Masyarakat Kota Lubuklinggau, 2) pemertahanan bahasa dengan status sebagai bahasa pendatang yang secara geografis dipengaruhi oleh bahasa mayoritas misalnya Pemertahanan Bahasa Bajo di Desa Tanjung Luar Kecamatan Keruak Lombok Timur, dan 3) pemertahanan bahasa melalui media elektronik seperti Pemertahanan Bahasa Melayu Palembang Melalui Media Elektronik oleh Emawati. Sedangkan persamaan antara penelitian sebelumnya dan penelitian ini adalah samasama memberi deskripsi atau mengetahui tentang situasi dan kondisi suatu bahasa daerah apakah masih dipertahankan atau telah mengalami pergeseran. Penelitian ini tidak hanya difokuskan pada ranah remaja dan dewasa tetapi juga ranah lain misalnya ranah orang tua, kemudian bahasa daerah yang ada di Negeri Laha adalah bahasa daerah asli (bukan bahasa pendatang yang dibawa oleh masyarakat tertentu), dan penelitian ini juga membahas tentang pemertahanan bahasa daerah yang ada dalam masyarakat di Negeri Laha.

\section{LANDASAN TEORI \\ Pengertian Sosiolinguistik}

Landasan teori dalam penelitian ini diarahkan kepada teori sosiolinguistik. Bram dan Dickey (Fathur Rokhman 2013, hlm. 2) menyatakan bahwa sosiolingustik mengkhususkan kajiannya pada bagaimana bahasa berfungsi di tengah masyarakat. Mereka menyatakan pula bahwa sosiolinguistik berupaya menjelaskan kemampuan manusia menggunakan aturanaturan berbahasa secara tepat dan bervariasi. Sosiolingusitik merupakan ilmu antardisiplin antara sosiologi dan linguistik, dua bidang ilmu empiris yang mempunyai kaitan sangat erat. Sosiolinguistik mencakup kedudukan bahasa dalam hubungannya dengan pemakaiannya di masyarakat serta merupakan ilmu antardisiplin yaitu dengan memadukan antara linguistik dan sosiologi yang memiliki kaitan erat antara satu dengan yang lainnya. Hal ini menandai bahwa sosiolinguistik merupakan bahasa pertama dalam sistem sosial dan sistem komunikasi, serta bagian dari masyarakat dan kebudayaan tertentu, sedangkan pemakaian bahasa adalah bentuk dari interaksi sosial yang terjadi pada situasi yang konkret (Suwito, 1983).

\section{Kedwibahasaan}

Mackey dalam I Nengah Suandi (2014, hlm. 12) kedwibahasaan bukan fenomena sistem bahasa melainkan fenomena pertuturan atau penggunaan bahasa, yakni praktik penggunaan bahasa secara bergantian. Istilah kedwibahasaan pada umumnya dipakai untuk menunjuk pada pemakaian atau penguasaan dua bahasa oleh 
seorang atau sebagian masyarakat bahasa. Istilah itu sering pula digunakan untuk mengacu pada situasi pemakaian tiga bahasa atau trilingualisme ataupun pemakaian lebih dari tiga bahasa atau multilingualisme. Untuk memakai dua bahasa, seseorang harus menguasai kedua bahasa itu. Orang yang dapat menggunakan kedua bahasa itu disebut dwibahasawan).

\section{Pemertahanan Bahasa}

Umumnya, pemertahanan bahasa mempunyai tujuan agar sebuah bahasa yang merupakan bagian dari budaya dapat berfungsi sebagai identitas kelompok atau komunitas, untuk memudahkan dalam mengenali anggota komunitas, dan sekaligus menyatukan persaudaraan sesama komunitas. Pemertahanan bahasa dapat terjadi jika suatu masyarakat bahasa masih tetap mempertahankan penggunaan bahasanya. Pemertahanan bahasa erat kaitannya dengan ranah yang berkaitan dengan pilihan bahasa (Rokhman, dalam Rianto, 2016). Pemertahanan bahasa sangat diperlukan oleh bangsa atau daerah untuk menunjukkan keberadaan dirinya. Apakah masih dikatakan bertahan atau telah punah. Konsep tentang pemertahanan bahasa adalah konsep yang terkait erat dengan perencanaan bahasa (Kaplan dalam Istianingrum, 2015). Keberadaan suatu bahasa tidak terlepas dari sikap para penutur bahasa yang bersangkutan. untuk menggunakannya dalam kehidupan sehari-hari (Maemunah. 2017)

Suandi (2014) mengemukakan bahwa sikap positif bahasa adalah menggunakan bahasa sesuai dengan situasi kebahasaan yang berkaitan dengan a) penggunaan bahasa sesuai dengan kaidah dan situasi bahasa; b) penggunaan bahasa sendiri tanpa dicampur dengan bahasa asing; dan c) penggunaan bahasa sesuai dengan keperluan. Sedangkan sikap negatif bahasa menyebabkan orang acuh tak acuh terhadap pembinaan pelestarian dan bahasanya. Ia tidak lagi merasa bangga menggunakan bahasanya sendiri sebagai identitas jati diri dan mereka merasa malu menggunakan bahasanya sendiri. Ini adalah yang menjadi penyebab orang beralih atau berpindah dari bahasanya sendiri ke bahasa yang lainnya. Kondisi seperti ini terjadi pada masyarakat bilingual maupun multilingual yang menganggap bahwa dengan bahasa yang baru akan lebih bergengsi dan lebih menjamin seseorang memperoleh kesempatan pada hal yang berhubungan dengan kemodernan ataupun semacamnya. Jika penutur suatu bahasa berpindah pada bahasa lain, maka hal ini menjadi suatu indikator bahwa orang tersebut mulai meninggalkan bahasanya yang berakibat bahasanya akan mengalami kematian atau kepunahan.

Masalah umum yang sering pula terjadi dalam masyarakat adalah kelompok/golongan yang berusia tua lebih bertahan pada bahasanya daripada kategori usia yang lebih muda. Hal ini diakibatkan karena kelompok yang lebih muda terpengaruh menggunakan bahasa yang baru yang menunjukkan adanya perubahan faktor kedinamisan. Dengan demikian, kecenderungan sikap negatif terhadap bahasa terjadi pada lapisan kelompok muda. Hal ini sejalan dengan pendapat Wijana (2011) bahwa pemertahanan bahasa oleh suatu masyarakat dipengaruhi oleh beberapa faktor yaitu: 1) kebanggaan berbahasa (linguistic pride); 2) kesadaran akan norma (awareness loyality) dan 3) loyalitas bahasa (language loyality).

Masyarakat Indonesia dikenal sebagai masyarakat yang heterogen baik dari segi suku, bahasa dan budayanya. Tingkat heterogenitas inilah yang menyebabkan adanya perbedaan dalam masyarakat sehingga dikenal sebagai masyarakat yang majemuk. Kemajemukan ini menunjukkan adanya keberagaman dari suatu masyarakat sehingga menimbulkan perbedaan. Sebagaimana dikemukakan oleh Nasikun (dalam Handoyo, 2015) bahwa perbedaan suku, bangsa, agama, adat istiadat, dalam suatu daerah secara horizontal disebut juga sebagai ciri masyarakat majemuk. Keberagaman bahasa dan penggunaan bahasa 
pada masyarakat Indonesia merupakan ciri kemajemukan masyarakat Indonesia sebagai masyarakat yang multingual.

Keberagaman masyarakat Indonesia yang kaya akan bahasa ini identik dengan India. Hal ini dikemukakan oleh Grosjean (dalam Muslihah, 2016) bahwa: Indonesia is a country which rich in language and culture, so famous as diversity community. It identikit with India, as said by Grosjean describes the phenomenon where a minority language in a multilingual nation that is influenced by the positive attitude of the speakers, and the attitude that tends tolerant of minority speakers across languages. It also same in Indonesian froe example: if native from particularly mother tongue caused of activity, time, probably will lost their mother tongue as someone's identity.

Kutipan di atas menjelaskan fenomena bangsa yang multilingual yaitu keberadaan bahasa minoritas dipengaruhi oleh sikap positif para penuturnya. Selain itu, sikap yang toleran terhadap para penutur antarbahasa minoritas juga sangat mendukung. Hal ini juga terjadi di Indonesia. Penutur yang berbeda bahasa daerah cenderung toleran terhadap penutur bahasa daerah yang lain pada saat berinteraksi dengan orang yang berlainan bahasa daerahnya yang menyebabkan suatu kelompok masyarakat menjadi multilingual. Masyarakat multilingual merupakan salah satu fenomena unik dalam kebahasaan karena masyarakat yang mendiami daerah tertentu. Bahasa daerah merupakan penamaan bahasa suatu kelompok masyarakat tertentu yang memperlihatkan frekuensi interaksi lebih tinggi di antara mereka dibandingkan dengan mereka yang tidak bertutur dalam bahasa daerah tersebut (Masinambow dan Paul Haenen, 2001).

\section{Pergeseran Bahasa}

Chaer dan Agustina (2010:142) pergeseran bahasa (language shift) menyangkut masalah penggunaan bahasa oleh seorang penutur atau sekelompok penutur yang bisa terjadi sebagai akibat perpindahan dari satu masyarakat tutur ke masyarakat tutur lain. Adanya pergeseran bahasa merupakan peristiwa yang alami akibat desakan dalam berkomunikasi dengan baik. Sumarsono dan Partana (2002) mengungkapkan bahwa pergeseran bahasa berarti suatu komunitas meninggalkan suatu bahasa sepenuhnya untuk memakai bahasa lain. Bila pergeseran sudah terjadi, para warga komunitas itu secara kolektif memilih bahasa baru. Banyak faktor terjadinya pergeseran bahasa seperti, loyalitas bahasa, konsentrasi wilayah pemukiman penutur, pemakaian bahasa pada ranah tradisional sehari-hari, kesinambungan peralihan bahasa ibuibu antargenerasi, pola-pola kedwibahasaan, mobilitas sosial, sikap bahasa, dan lain-lain.

Sebuah bahasa disebut mati atau punah jika tidak seorang pun yang bisa menuturkan atau menggunakan bahasa tersebut. Menurut Crystal (2000) sekurang-kurangnya ada empat alasan pemertahanan suatu bahasa, (1) bahasa memerlukan keberagaman, (2) bahasa menunjukkan identitas, (3) bahasa adalah gudang sejarah, dan (4) karena dalam bahasa ada hal yang menarik. Berdasarkan tingkat keterancaman atau kepunahan suatu bahasa Grenoble dan Whaley (dengan merujuk kriteria yang digunakan oleh UNESCO mendeskripsikan enam skala keterancaman dan kepunahan suatu bahasa yaitu (1) bahasa yang aman; (2) bahasa yang berisiko; (3) bahasa yang mulai terancam; (4) bahasa dalam kondisi sakit; (5) bahasa yang hampir punah/sekarat; dan (6) bahasa yang punah. Berdasarkan laju atau kecepatan berlangsungnya kepunahan, Campbell dan Muntzel membedakan kepunahan bahasa ke dalam empat kategori, yakni kepunahan mendadak (sudden attrition), kepunahan radikal (radical attrition), kepunahan bertahap (gradual attrition), dan kepunahan dari bawah ke atas (bottom-to-top attrition). Tasaku Tsunoda juga membagi tingkatan bahaya terhadap pemertahanan bahasa yang diistilahkan oleh Tasaku Tsunoda dengan Degree of Language Endangerment. Menurut Tsunoda, situasi yang mengancam pemertahanan bahasa terbagi atas empat tingkatan yaitu bahasa 
yang sehat, bahasa yang sakit, bahasa yang sekarat, dan bahasa yang punah.

\section{METODE PENELITIAN}

Penelitian ini merupakan penelitian deskriptif kuantitatif. Populasi dalam penelitian ini adalah masyarakat Negeri Laha yang berdomisili di Negeri Laha Kecamatan, Teluk Ambon, Kota Ambon. Sampel dalam penelitian ini berjumlah 50 responden, berusia remaja/dewasa hingga tua. Sampel diambil secara acak (random sampling). Secara spesifik, instrumen dalam penelitian ini berupa angket/kuesioner yang berisi pertanyaan-pertanyaan yang dijawab responden yang berjumlah 50 orang. Teknik pengumpulan data dalam penelitian melalui kuesioner, merupakan teknik pengumpulan data yang harus dijawab oleh responden terhadap pertanyaan-pertanyaan yang telah disiapkan oleh peneliti. Selain itu, peneliti juga melakukan wawancara dengan tokoh masyarakat, tetua adat, tokoh pemuda, dan beberapa masyarakat lain yang mengetahui tentang bahasa daerah di Kota Ambon. Tokoh dan masyarakat yang diwawancarai berasal dari Negeri Laha maupun di beberapa negeri adat yang berada di wilayah Kota Ambon. Setelah dilakukan penjaringan data, kemudian data dikumpulkan, lalu dianalisis berdasarkan jawaban responden dan hasil wawancara secara kuantitatif. Setelah itu, dilanjutkan dengan reduksi data untuk menajamkan, menggolongkan, mengarahkan, membuang yang tidak perlu dan mengorganisasi data, kemudian dilanjutkan dengan penyajian atau display data, dan berakhir pada penarikan kesimpulan.

\section{PEMBAHASAN}

\section{Pemertahanan Bahasa Daerah di Negeri Laha}

Pemertahanan bahasa daerah di Negeri Laha yang disebut sebagai bahasa Asilulu dialek Laha dalam pembahasan ini meliputi data umum responden, penguasaan bahasa daerah masyarakat Negeri Laha, kemampuan masyarakat dalam berbahasa daerah berdasarkan usia, bahasa yang digunakan ketika pada masa kecil (anakanak), bahasa pertama yang dipelajari, masa kemampuan penguasaan bahasa daerah di Negeri Laha, pemerolehan belajar bahasa daerah, dan tingkat kemampuan berbahasa berbahasa daerah. Penjelasan detail di atas untuk menggambarkan tentang situasi dan kondisi bahasa daerah yang ada di Negeri Laha pada saat ini.

\section{Data Umum Responden}

Data umum responden terdiri atas nama, usia, tempat lahir, status perkawinan, jenis kelamin, pendidikan, pekerjaan, dan tempat tinggal. Rincian data umum responden dapat dilihat pada tabel 1 berikut.

Tabel 1

Rekapitulasi Data Umum Responden

\begin{tabular}{|c|c|c|c|c|c|c|c|c|c|c|}
\hline \multicolumn{2}{|c|}{$\begin{array}{c}\text { Jenis } \\
\text { Kelamin }\end{array}$} & \multicolumn{3}{c|}{$\begin{array}{c}\text { Status } \\
\text { (Tahun) }\end{array}$} & \multicolumn{3}{c|}{ Pendidikan Terakhir } \\
\hline L & P & $15-25$ & $25-40$ & $\begin{array}{c}41-\text { Ke } \\
\text { Atas }\end{array}$ & Kawin & $\begin{array}{c}\text { Belum } \\
\text { Kawin }\end{array}$ & SD & SMP & SMA & PT \\
\hline 26 & 24 & 5 & 23 & 22 & 44 & 6 & 2 & 4 & 38 & 6 \\
\hline
\end{tabular}

Berdasarkan tabel 1 di atas, jenis kelamin responden hampir berimbang yaitu laki-laki berjumlah 26 responden, dan perempuan sebanyak 24 responden. Untuk usia responden bervariasi yang dimulai dari usia 15 tahun hingga usia di atas 41 tahun ke atas. Terdapat tiga kategori usia dalam penelitian yaitu 15-25 tahun sebanyak 5 responden, usia 25-40 tahun berjumlah 23 responden, dan usia 41 tahun ke atas 
sebanyak 22 responden. Untuk Status perkawinan dalam penelitian ini, tampak didominasi oleh kawin sebesar 44 responden, dan belum kawin hanya sebanyak 6 responden. Untuk pendidikan terakhir responden tersebar pada semua tingkatan meskipun didominasi dari tingkatan sekolah menengah atas (SMA) dengan rincian sekolah dasar (SD) berjumlah 2 responden, sekolah menengah pertama (SMP) sebanyak 4 responden, sekolah menengah atas (SMA) sebanyak 38 responden, dan perguruan tinggi $(\mathrm{PT})$ sebanyak 6 responden.

\section{Penguasaan Bahasa Daerah Masyarakat Negeri Laha}

Penguasaan bahasa daerah pada masyarakat Negeri Laha tampak terlihat pada jawaban responden pada pertanyaan yang diberikan. Pertanyaan tersebut terkait dengan kemampuan berkomunikasi dalam bahasa daerah di Negeri Laha. Sebagai hasilnya, disajikan pada tabel berikut.

Tabel 2

Penguasaan Bahasa Daerah Masyarakat Negeri Laha

\begin{tabular}{|c|c|c|}
\hline \multicolumn{3}{|c|}{ Apakah Bisa Berbahasa Daerah Laha? } \\
\hline Ya & $\begin{array}{c}\text { Sedikit- } \\
\text { Sedikit }\end{array}$ & Tidak \\
\hline 21 & 27 & 2 \\
$(42 \%)$ & $(54 \%)$ & $(4 \%)$ \\
\hline
\end{tabular}

Sumber: Data diolah, 2020

Berdasarkan tabel 2 di atas berhubungan dengan kemampuan penguasaan berkomunikasi dalam bahasa daerah di Negeri Laha tampak bahwa yang bisa berbahasa daerah Laha sebanyak 21 orang atau $42 \%$, kemudian bisa berkomunikasi sedikit-sedikit berjumlah 27 orang atau $54 \%$, dan yang tidak bisa sama sekali berbahasa daerah di Negeri Laha 2 orang atau 4\%. Mengacu hasil jawaban responden di atas, kemampuan responden dalam berkomunikasi dalam bahasa daerah
Laha lebih banyak hanya bisa berkomunikasi secara sedikit-sedikit daripada bisa berkomunikasi secara aktif, bahkan ada yang sama sekali tidak bisa berkomunikasi dalam bahasa daerah di Negeri Laha. Menurut wawancara dan pengamatan responden di Negeri Laha, kemampuan berbahasa secara sedikitsedikit yang dimaksud hanya bisa memahami saja tetapi tidak bisa berkomunikasi atau berdialog secara interaktif. Responden hanya bisa bersifat pasif. Jika pun terjadi komunikasi dua arah, itu direspons dengan menggunakan bahasa Indonesia atau dialek Ambon/Melayu Ambon antara pembicara dan lawan bicara.

\section{Kemampuan Masyarakat dalam Berbahasa Daerah Berdasarkan Usia}

Kemampuan masyarakat dalam berbahasa daerah Laha berdasarkan usia diukur dari pertanyaan dalam kuesioner apakah bisa berbahasa daerah Laha. Pilihan pilihan jawaban meliputi ya, sedikit-sedikit, dan tidak. Hasil didapatkan dengan mengacu pada usia responden yang dikategori 4 kelompok usia yaitu di bawah 30 tahun, 30-40 tahun, 41-50, dan di atas 50 tahun. Sebagai hasilnya disajikan dalam tabel 3 berikut.

\section{Tabel 3}

Kemampuan Masyarakat dalam Berbahasa Daerah Di Negeri Laha Berdasarkan Usia

\begin{tabular}{|l|c|c|c|}
\hline \multirow{2}{*}{$\begin{array}{l}\text { Kategori } \\
\text { Usia }\end{array}$} & \multicolumn{3}{|c|}{$\begin{array}{c}\text { Apakah Bisa Berbahasa } \\
\text { Daerah Laha? }\end{array}$} \\
\cline { 2 - 4 } & Ya & $\begin{array}{c}\text { Sedikit- } \\
\text { Sedikit }\end{array}$ & Tidak \\
\hline $\begin{array}{l}\text { Di bawah } \\
30\end{array}$ & 4 & 7 & - \\
\hline $30-40$ & 4 & 9 & 2 \\
\hline $41-50$ & 2 & 10 & - \\
\hline
\end{tabular}




\begin{tabular}{|l|c|c|c|}
\hline Di atas 50 & 11 & 1 & - \\
\hline Jumlah & $\mathbf{2 1}$ & $\mathbf{2 7}$ & $\mathbf{2}$ \\
& $\mathbf{4 2 \%}$ & $\mathbf{5 4 \%}$ & $\mathbf{4 \%}$ \\
\hline
\end{tabular}

Sumber: Data Diolah, 2020

Berdasarkan tabel di atas menunjukkan bahwa dari sebanyak 50 responden, jumlah responden yang bisa berbahasa daerah di Negeri Laha didominasi kalangan usia di atas 50 tahun yaitu sebanyak 11 responden, kemudian diikuti usia 41-50 tahun dan usia di bawah 30 tahun masing-masing sebanyak 4 orang, dan usia 41-50 tahun 2 orang. Kemudian jumlah responden yang bisa berbahasa daerah di Negeri Laha kategori sedikitsedikit lebih banyak pada usia $41-50$ yaitu sebanyak 10 orang, diikuti usia $30-40$ tahun sebanyak 9 orang, usia di bawah 30 tahun sebanyak 7 orang, dan usia di atas 50 tahun 1 orang. Sedangkan responden yang sama sekali tidak bisa berbahasa daerah yaitu 2 orang yang berusia $30-40$ tahun. Dengan demikian, dapat digambarkan bahwa usia di atas 50 tahun terkategori banyak yang bisa berkomunikasi dalam bahasa daerah Laha, sedangkan usia di bawah 50 tahun hanya bisa berbicara bahasa daerah sedikit-sedikit bahkan ada beberapa responden yang benar-benar tidak paham bahasa daerah yang ada di Negeri Laha. Dengan melihat data usia di atas, jika bahasa daerah di Negeri Laha dibiarkan atau terbiarkan begitu saja atau tanpa dilakukan solusi penyelamatan secara cepat dan tepat seperti dalam bentuk konservasi dan revitalisasi, maka dapat diprediksi dalam waktu yang tidak lama, maka bahasa daerah di Negeri Laha akan punah seiring dengan kematian para penutur yang sekarang kebanyakan berusia di atas 50 tahun.

\section{Bahasa yang Digunakan Ketika pada Masa Kecil (Anak-Anak)}

Responden juga ditanyakan tentang bahasa yang digunakan pada saat masa kecil (anak-anak). Sebagai pilihan jawaban yang disediakan adalah bahasa daerah, bahasa Indonesia/Melayu Ambon, dan bahasa lain. Adapun hasilnya dapat dilihat pada tabel berikut.

Tabel 4

Bahasa yang Digunakan pada Masa
Kecil (Anak-Anak)

\begin{tabular}{|c|l|l|}
\hline $\begin{array}{l}\text { Bahasa } \\
\text { Daerah Di } \\
\text { Negeri Laha }\end{array}$ & $\begin{array}{l}\text { Bahasa } \\
\text { Indonesia/Melayu } \\
\text { Ambon }\end{array}$ & $\begin{array}{l}\text { Bahasa } \\
\text { Lain }\end{array}$ \\
\hline 28 & 22 & - \\
$(56 \%)$ & $(44 \%)$ & $(0 \%)$ \\
\hline
\end{tabular}

Sumber: Data Diolah, 2020

Berdasarkan tabel 4 di atas dapat digambarkan bahwa bahasa yang digunakan pada masa kecil (anak-anak) yaitu bahasa daerah Laha sebanyak 28 orang atau $56 \%$, bahasa Indonesia sebanyak 22 orang atau $44 \%$, dan bahasa lain tidak ada yang menjawab. Mengacu hasil jawaban responden di atas menunjukkan bahwa penggunaan bahasa pada saat masih kecil lebih banyak menggunakan bahasa daerah Laha dibandingkan bahasa Indonesia/Melayu Ambon. Selain itu, pada tabel di atas menunjukkan pula bahwa penggunaan bahasa daerah di Negeri Laha pada saat usia kecil/anak-anak lebih banyak dibandingkan bahasa Indonesia/Melayu Ambon. Meskipun demikian, berdasarkan tabel 4 di atas juga tergambar bahwa ketika usia kecil/anak-anak, banyak pula responden menggunakan bahasa Indonesia/Melayu Ambon. Artinya, pemakaian bahasa Indonesia/Melayu Ambon telah menjadi komunikasi seharihari dalam masyarakat ketika berusia anakanak. Merujuk hasil tabel di atas pula bahwa antara bahasa daerah dan bahasa Indonesia/Melayu Ambon pada saat responden masa anak-anak digunakan hampir saling bersaing. Kedua bahasa 
tersebut menjadi komunikasi sehari-hari baik dalam ranah formal/resmi maupun ranah nonformal/tidak resmi. Dapat pula digambarkan bahwa ketika responden berusia anak-anak bahkan boleh jadi sebelum itu, pengaruh bahasa Indonesia/Melayu Ambon begitu kuat dalam komunikasi sehari-hari. Dengan demikian, pada saat itu bahasa daerah yang ada dan digunakan di Negeri Laha telah terancam dari segi pemakaiannya yang tentu penyebab utamanya adalah keberadaan pemakaian bahasa Indonesia/Melayu Ambon dalam masyarakat.

\section{Bahasa Pertama yang Dipelajari}

Bahasa pertama yang dipelajari oleh responden dalam kuesioner penelitian ini meliputi bahasa daerah, bahasa Indonesia/Melayu Ambon, dan bahasa lain. Bahasa pertama yang dipelajari yang dimaksudkan di sini adalah pertama kali responden belajar berbahasa atau berkomunikasi dalam aktivitas sehari-hari. Adapun jawaban responden dapat dilihat pada tabel 5 berikut.

\section{Tabel 5}

Bahasa Pertama yang Dipelajari

\begin{tabular}{|c|l|l|l|}
\hline \multicolumn{4}{|c|}{ Bahasa Pertama yang Dipelajari } \\
\hline Bahasa & Bahasa & Bahasa & Tidak \\
Daerah & $\begin{array}{l}\text { Indonesia } \\
\text { /Melayu } \\
\text { Ambon }\end{array}$ & $\begin{array}{l}\text { Lenja } \\
\text { wab }\end{array}$ \\
\hline 34 & 15 & - & 1 \\
$68 \%)$ & $(30 \%)$ & $(0 \%)$ & $(2 \%)$ \\
\hline
\end{tabular}

\section{Sumber: Data Diolah, 2020}

Berdasarkan tabel 5 di atas, dari 50 responden tampak terlihat bahwa bahasa pertama yang dipelajari oleh responden adalah bahasa daerah sebanyak 34 orang atau $68 \%$, kemudian 15 orang atau $30 \%$ menjawab bahasa Indonesia/Melayu Ambon, bahasa daerah lain tidak ada yang menjawab, dan 1 orang tidak menjawab atau 2\%. Mengacu kepada tabel di atas dapat dijelaskan bahwa pembelajaran bahasa pertama kali didominasi oleh bahasa daerah dibandingkan bahasa Indonesia/Melayu Ambon.

\section{Masa Kemampuan Penguasaan Bahasa Daerah Laha}

Masa kemampuan penguasaan bahasa daerah di Negeri Laha yang ditanyakan kepada responden adalah sejak kapan mampu menguasai bahasa daerah Laha. Pilihan jawaban terdapat tiga alternatif yaitu sejak anak-anak, sejak masa sekolah, dan sejak berusia dewasa. Jawaban responden disajikan dalam daftar tabel 6 berikut.

Tabel 6

Masa Penguasaan Bahasa Daerah di Negeri Laha

\begin{tabular}{|c|c|c|c|}
\hline \multicolumn{4}{|c|}{$\begin{array}{c}\text { Masa Kemampuan Penguasaan } \\
\text { Bahasa Daerah }\end{array}$} \\
\hline $\begin{array}{l}\text { Sejak } \\
\text { Anak- } \\
\text { Anak }\end{array}$ & $\begin{array}{c}\text { Sejak } \\
\text { Masa } \\
\text { Sekolah }\end{array}$ & $\begin{array}{c}\text { Sejak } \\
\text { Dewasa }\end{array}$ & $\begin{array}{l}\text { Tidak } \\
\text { Menja } \\
\text { wab }\end{array}$ \\
\hline $\begin{array}{c}36 \\
(72 \%)\end{array}$ & $\begin{array}{c}6 \\
(12 \%)\end{array}$ & $\begin{array}{c}- \\
(0 \%)\end{array}$ & $\begin{array}{c}8 \\
(16 \%)\end{array}$ \\
\hline
\end{tabular}

Sumber: Data Diolah, 2020

Berdasarkan tabel 6 di atas dapat dilihat bahwa dari 50 responden, masa penguasaan bahasa daerah terdapat 36 orang atau $72 \%$ menjawab sejak anak-anak, 6 orang atau $12 \%$ menjawab sejak sekolah, tidak ada yang menjawab sejak masa dewasa, dan 8 orang atau $16 \%$ tidak menjawab. Artinya kemampuan penguasaan bahasa daerah paling banyak diperoleh dari sejak anak-anak. Dengan 
demikian, pemerolehan dan penggunaan bahasa daerah lebih terpelihara atau terjaga ketika responden berusia anak-anak. Di samping itu juga sekaligus menggambarkan bahwa jumlah pengguna atau penutur bahasa daerah pada saat kecil/anak-anak lebih banyak.

\section{Pemerolehan Belajar Bahasa Daerah}

Pada bagian ini yang ditanyakan kepada responden yaitu di lingkungan mana belajar bahasa daerah. Pilihan jawaban di sekolah, lingkungan keluarga, dan lingkungan masyarakat. Jawaban responden disajikan dalam tabel berikut.

\section{Tabel 7}

Pemerolehan Belajar Bahasa Daerah

\begin{tabular}{|c|c|c|c|}
\hline \multicolumn{4}{|c|}{ Pemerolehan Belajar Bahasa Daerah } \\
\hline Sekolah & Keluarga & Masyarakat & $\begin{array}{l}\text { Tidak } \\
\text { Menjawab }\end{array}$ \\
\hline $\mathbf{5}$ & $\mathbf{3 8}$ & $\mathbf{6}$ & $\mathbf{1}$ \\
$\mathbf{( 1 0 \% )}$ & $\mathbf{( 7 6 \% )}$ & $\mathbf{( 1 2 \% )}$ & $\mathbf{( 2 \% )}$ \\
\hline
\end{tabular}

Sumber: Data Diolah, 2020

Berdasarkan tabel 7 dapat dilihat bahwa dari 50 responden yang ada, lingkungan tempat belajar bahasa daerah sebanyak 5 orang atau $10 \%$ menjawab di sekolah, 38 orang atau $76 \%$ di lingkungan keluarga, dan 6 orang atau $12 \%$ di lingkungan masyarakat, serta 1 orang atau $2 \%$ tidak menjawab. Mengacu kepada hasil tabel di atas dapat dijelaskan bahwa lingkungan atau tempat pembelajaran bahasa daerah didominasi dari lingkungan keluarga. Dapat pula digambarkan bahwa keadaan bahasa daerah di lingkungan keluarga ketika pemerolehan pembelajaran bahasa daerah masih terpelihara atau terjaga minimal masih dapat berkomunikasi dalam aktivitas sehari-hari di lingkungan keluarga. Pada saat pemerolehan pembelajaran bahasa daerah, lingkungan keluarga menjadi tempat yang tepat atau sesuai.

\section{Tingkat Kemampuan Berbahasa Berbahasa Daerah}

Bagian ini menggambarkan tingkat kemampuan responden dalam berbahasa daerah. Yang ditanyakan kepada responden yaitu tingkat kemampuan berbahasa berbahasa daerah. Pilihan jawaban terdiri atas bisa berbicara dengan lancar, hanya bisa berbicara sedikit-sedikit, hanya bisa memahami tetapi tidak bisa bicara, dan tidak bisa memahami sama sekali. Adapun jawaban responden disajikan dalam daftar tabel berikut.

\section{Tabel 8}

Tingkat Kemampuan Berbahasa Daerah

\begin{tabular}{|c|c|c|c|c|}
\hline \multicolumn{5}{|c|}{ Tingkat Kemampuan Berbahasa Daerah } \\
\hline BBL & HBBS & HMTBB & TBMS & $\begin{array}{c}\text { Tidak } \\
\text { Menjawab }\end{array}$ \\
\hline $\mathbf{2 5}$ & $\mathbf{1 6}$ & $\mathbf{3}$ & - & $\mathbf{6}$ \\
$(\mathbf{5 0 \%})$ & $\mathbf{( 3 2}$ & $(\mathbf{6 \% )}$ & $(\mathbf{0 \%})$ & $\mathbf{( 1 2 \% )}$ \\
& \%) & & & \\
\hline
\end{tabular}

$$
\begin{aligned}
\text { Sumber: Data } & \text { Diolah, } 2020 \\
\text { BBL } & \text { bisa berbicara dengan lancar } \\
\text { HBBS } & \text { hanya bisa berbicara sedikit- } \\
& \text { sedikit } \\
\text { HMTBB }= & \text { Hanya bisa memahami tetapi } \\
& \text { tidak bisa bicara } \\
\text { TBMS } & \text { tidak bisa memahami sama } \\
& \text { sekali }
\end{aligned}
$$

Berdasarkan tabel 8 di atas, tampak bahwa dari 50 responden yang ada, tingkat kemampuan berbahasa daerah terdapat 25 responden atau 50\% menjawab bisa berbicara lancar, 16 orang atau $32 \%$ bisa bicara sedikit-sedikit, 3 orang hanya bisa memahami tetapi tidak bisa berbicara, dan 6 atau $12 \%$ tidak menjawab.

\section{PENUTUP}

Berdasarkan pembahasan dan analisis data dalam penelitian ini dapat disimpulkan bahwa bahasa daerah di Negeri Laha masih dituturkan di Negeri Laha Kota 
Ambon. Meskipun demikian, pemertahanan bahasa daerah di Negeri Laha yang merupakan satu-satunya bahasa daerah yang masih ada di Kota Ambon telah mengalami pergeseran dan dalam kategori bahasa yang terancam punah. Hal itu terlihat dari segi pemakai dan pemakaiannya di masyarakat Negeri Laha. Pemakai dan pemakaiannya mengacu pada penguasaan bahasa daerah masyarakat Negeri Laha, kemampuan masyarakat dalam berbahasa daerah berdasarkan usia, bahasa yang digunakan ketika pada masa kecil (anak-anak), bahasa pertama yang dipelajari, masa kemampuan penguasaan bahasa daerah di Negeri Laha, pemerolehan belajar bahasa daerah, dan tingkat kemampuan berbahasa berbahasa daerah di Negeri Laha. Kemampuan penguasaan dalam berkomunikasi dalam bahasa daerah di Negeri Laha lebih banyak hanya bisa berkomunikasi secara sedikit-sedikit

\section{DAFTAR PUSTAKA}

Badan Pengembangan dan Pembinaan Bahasa dan Perbukuan, Kementerian Pendidikan dan Kebudayaan, 2019. Bahasa dan Peta Bahasa di Indonesia. ((http://petabahasa.kemdikbud.go.i d). Diakses 17 September 2020.

Badan Pusat dan Statistik Kota Ambon, 2017. Sosial dan Kependudukan. (https://ambonkota.bps.go.id). Diakses 20 September 2020

Chaer, Abdul dan Leonie Agustina. 2010. Sosiolinguistik. Jakarta: Rineka Cipta.

Crystal, David. 2002. Language Death. Cambridge: Cambridge University.

Darwis, M. (2011). Nasib Bahasa Daerah di Era Globalisasi: Peluang dan Tantangan. Paper presented at the Makalah disampaikan pada daripada bisa berkomunikasi secara aktif. Dari segi usia, kebanyakan yang bisa dan lancar berbahasa daerah Laha rata-rata usia di atas 50 tahun. Untuk usia di bawah usia 50 tahun, kebanyakan hanya bisa berkomunikasi sedikit-sedikit, hanya bisa memahami (pasif), dan bahkan sebagian pula tidak bisa berkomunikasi sama sekali. Jika suatu bahasa daerah telah dalam kondisi terancam punah kemudian dibiarkan atau terbiarkan saja tanpa diikuti pencegahan secara cepat dan tepat, maka bisa diprediksi dalam waktu yang tidak lama, bahasa tersebut akan punah seiring dengan kematian para penutur yang berusia tua. Bahasa daerah di Negeri Laha adalah milik dan aset budaya kita bersama khususnya bagi masyarakat Negeri Laha itu sendiri dan milik masyarakat Kota Ambon umumnya.

Workshop Pelestarian Bahasa

Daerah Bugis Makassar, Parepare.

Handoyo, Eko A. T. (2015). Studi
Masyarakat
Yogyakarta: Ombak.

Istianingrum, Rika. 2015. Degradasi Bahasa Dayak Kenyah. Diakses tanggal 9 Januari 2020 dari Jurnal Stilistika. 8(2)

Maemunah, Emma. 2017. Pemakaian Bahasa Jawa Keluarga Muda di Karesidenan Semarang. Balai Bahasa Provinsi Jawa Tengah. Diakses Jurnal Jalabahasa. (13)1

Masinambouw dan Paul Haenen. 2001. Sosiolinguistik. Jakarta: Erlangga

Muslihah, Nur Nisai. (2016). Society's Attitudes toward Indonesia and Perspective in Facing the ASEAN 
Totobuang, Vol. 9, No. 2, Desember 2021: 331-342

Economic Community. Paper dipresentasikan di ICEL4Tth The Fourth International Conference on Education and Language. Bandar Lampung, University Indonesia.

Nugroho, Hasan. (2017). Pemertahanan Bahasa sebagai Strategi komunikasi pada Kegiatan Tutorial (Pembelajaran BIPA Kelas Pemula). Diakses 1 Oktober 2020 dari Jurnal Wacana. 1(1)

Rianto, Sugeng dan Wagiati. (2016). Pemertahanan Bahasa Sunda oleh Mahasiswa yang Berbahasa Pertama Sunda. Diakses 26 Desember 2018, 2 dari Jurnal Metalingua. 14(2).
Rokhman, Fathur. 2013. Sosiolinguistik Suatu Pendekatan Pembelajaran Bahasa dalam Masyarakat Multiultural. Yogyakarta: Graha Ilmu.

Suandi, I.N. 2014. Sosiolinguistik. Yogyakarta: Graha Ilmu

Sumarsono dan Paina Partana. 2002. Sosiolinguistik. Yogyakarta: Penerbit Sabda.

Suwito. 1983. Pengantar Awal Sosiolinguistik Teori dan Problema. Surakarta UNS Press

Wijana, D. d. (2011). Sosiolinguistik Kajian Teori dan Analisis. Yogyakarta: Pustaka Pelajar 